https://doi.org/10.31516/2410-5325.066.04

UDC 378.4.091.214:008](417)(045)

O. S. Chastnyk, Cand. of Art Criticism, Associate Professor, Yaroslav Mudryi National Law University, Kharkiv

chastnyk@gmail.com

http://orcid.org/0000-0001-5188-5097

\title{
CULTURAL STUDIES IN DEGREE PROGRAMMES AT IRISH UNIVERSITIES 1
}

The author examines the main characteristic features of degree programmes in Cultural studies taught at Irish universities. The results indicate that the content and research methodology of most analysed programmes are more similar to Ukrainian Culturology courses than to classical Cultural studies. Of particular interest are international and inter-university projects with a comparative analysis of different cultures, as well as innovative interdisciplinary programmes of practical value that have no direct correspondence in the practice of teaching Culturology. In the author's opinion, the idea of replacing Culturology with "more progressive" Cultural studies is unfounded. Coordinating curricula in Culturology with European standards of higher education does not mean giving up national achievements and identity.

Keywords: university, culture, educational programmes, culturology, cultural studies, Ireland.

А. С. Частник, кандидат искусствоведения, доцент, Национальный юридический университет им. Ярослава Мудрого, г. Харьков

\section{ИССЛЕДОВАНИЯ В ОБЛАСТИ КУЛЬТУРЫ (CULTURAL STUDIES) В ОБРАЗОВАТЕЛЬНЫХ ПРОГРАММАХ УНИВЕРСИТЕТОВ ИРЛАНДИИ}

Рассмотрены направления и методы исследований в области знаний, известной на Западе под названием cultural studies на примере образовательных программ ирландских университетов. Установлено, что большая часть этих программ содержательно и методологически гораздо ближе к отечественным курсам культурологии и искусствоведения, чем к классическим cultural studies. Выявлено, что заслуживают внимания международные и межуниверситетские проекты с компаративным анализом разных культур, а также инновационные междисциплинарные программы прагматичной направленности, не имеющие прямых аналогов в практике преподавания культурологии. Отмечено, что утверждения о необходимости замены культурологии на «более прогрессивные» cultural studies являются безосновательными. Доказано, что согласование учебных планов по культурологии с европейскими стандартами высшего образования не означает отказа от отечественных достижений и собственной идентичности.

Ключевые слова: университет, культура, образовательные программы, cultural studies, Ирландия.

1 This work is licensed under a Creative Commons Attribution-NonCommercialShareAlike 4.0 International License. 
О. С. Частник, кандидат мистецтвознавства, доцент, Національний юридичний університет ім. Ярослава Мудрого, м. Харків

\section{ДОСЛІДЖЕННЯ В ГАЛУЗІ КУЛЬТУРИ (CULTURAL STUDIES) В ОСВІТНІХ ПРОГРАМАХ УНІВЕРСИТЕТІВ ІРЛАНДІЇ}

Актуальність. Наше суспільство характеризується швидким зростанням ролі університетів у поширенні знань та формуванні інтелектуальної еліти. Порівняно легкий доступ до вищої освіти в деяких країнах ЄС та відкритість європейських кордонів $є$ серйозними викликами для українських університетів. Для виживання в конкурентній боротьбі українським закладам вищої освіти потрібна, зокрема, інформація про навчальні програми та напрями досліджень західних університетів у споріднених галузях знань. Критичний аналіз такої інформації надасть змоги об'єктивніше оцінити власну ідентичність та визначити, який зарубіжний досвід слід запозичити, а який - ні. Особливо актуальним у цьому плані $€$ вивчення освітніх програм у галузі культури, оскільки дослідження в цій галузі сприяють кращому розумінню сучасних цивілізаційних процесів.

Мета статті - проаналізувати основні характерні ознаки навчальних програм із cultural studies, що викладаються в ірландських університетах. У контексті нинішньої дискусії «Культурологія vs Cultural studies» слід звернути увагу, які елементи cultural studies доцільно запозичити для викладання культурології в закладах вищої освіти України.

Методологія. У статті використовуються описовий, порівняльний та класифікаційний підходи.

Результати. Аналіз матеріалу виявив велику різноманітність підходів до вивчення культури в Ірландії, починаючи від розгляду загальних теоретичних аспектів до вивчення конкретних культур. Теоретичні питання викладаються в класичних університетах, водночас програми менших закладів часто спрямовані на практичне застосування набутих в університеті навичок та знань. Типовими для більшості курсів $€$ поєднання ідей і методів, запозичених у різних соціальних та гуманітарних наук, а також спрямованість на вивчення культурних інститутів сучасного суспільства. Виявлено, що більшість із цих програм змістовно і методологічно набагато ближчі до українських курсів культурології та мистецтвознавства, аніж до класичних cultural studies. Чимало програм зосереджуються на вивченні фольклору, етнології та мистецтва, тобто галузей знань, які активно викладаються в Україні. Водночас доцільно уважніше ознайомитися з такими інноваційними курсами на перетині гуманітарних наук, обчислень та управління інформацією, як Digital Humanities; Порівняльна література та cultural studies; Культурні відмінності та перехідні процеси. Заслуговують на увагу міжнародні та міжуніверситетські проекти з компаративним аналізом різних культур, а також інноваційні міждисциплінарні програми прагматичного спрямування, які не мають прямих аналогів у практиці викладання культурології. Схоже також, що ірландські університети надають ширші кар'єрні можливості у сфері культури, аніж аналогічні навчальні заклади в Україні. Доцільно доповнити українські програми з культурології спеціальним курсом, що стосується досвіду викладання cultural studies у західних університетах. 
Новизна. Стаття являє собою першу спробу систематизувати навчальні програми з cultural studies в ірландських університетах та порівняти їх 3 курсами культурології, що викладаються в українських ЗВО.

Практичне значення. Матеріали цієї статті можуть стати в нагоді українським професіоналам, які розробляють курси культурології.

Ключові слова: університет, культура, освітні програми, cultural studies, культурологія, Ірландія.

Problem statement. Our society is characterized by rapid growth of the role of universities in the dissemination of knowledge and the formation of the intellectual elite. The relatively easy access to higher education in some EU countries and the openness of European borders present serious challenges to Ukrainian universities. To survive in competition, Ukrainian higher education institutions need, in particular, information on curricula and research areas of Western universities in related fields of knowledge. A critical analysis of such information will allow us to evaluate our identity more objectively and to determine what foreign experience is worth borrowing and what is not. Particularly relevant in this regard is the study of educational programmes in the field of culture, because research in this field contribute to a better understanding of modern civilization processes.

The purpose of the article is to review the content and research methods of a range of humanities known in the West under the title of "cultural studies". The materials for analysis are drawn from curricula in cultural studies adopted at the universities of the Republic of Ireland. This choice was made, first of all, because of the high quality of higher education in Ireland, attractive to applicants from many countries, including Ukraine. In the context of the "culturology vs cultural studies" discussion, it is also interesting to see whether the claims of culturology's "lagging behind" from Western approaches to the study of culture are well-founded.

Previous research. The main conceptual provisions of cultural studies are outlined, for example, in (Grossberg \& Radway, 1994) and in The Cultural studies Reader, ed. by S. During (During, 1999). In this book, S. Hall, G. Spivak and other well-known researchers analyse various stages of the development of cultural studies from the emergence as an independent discipline to the present state and prospects for the future. Other authors consider, in particular, the problems of globalization, postcolonialism, postmodernism and state policy in the field of culture. Reading Digital Culture (Trend, 2001), Media and Cultural studies (Durham \& Kellner, 2012) deal with the study of new forms of culture in information society. The range of issues discussed in these writings is typical of the British school of cultural studies: the relation of culture to such phenomena of modern social life as nationalism and identity, regionalism, digital communication, feminism, postmodernism, etc. 
The standards of culturology as a science and academic discipline are outlined in (Sheyko, Kanistratenko \& Kushnarenko, 2018, p. 64). The conceptual apparatus, theoretical principles, goals and methods of culturology are described in (Sheyko, Bohutskyi, \& Germanova de Diaz, 2012).

The early $21^{\text {st }}$ century witnessed a lively debate in the post-Soviet educational environment as to the feasibility of further teaching culturology at higher education institutions and replacing this discipline with "more progressive" cultural studies (see, e.g, Zvereva, 2008; Nurzhanov \& Yerzhanova, 2010). The arguments of the supporters of this idea often contradict each other; worth noticing, however, is a serious analysis of the common features of culturology and cultural studies and the differences between them. Also discussed are the differences between cultural studies and cultural anthropology; in Ukrainian tradition the latter is treated as a field of culturology (Sheyko, Bohutskyi \& and Germanova de Diaz, 2012, p. 33).

The main text. Culturology is defined as "a humanitarian discipline that studies culture as a whole system, diversity of cultures in space and time, interaction of cultures, types of cultures, patterns of development of sociocultural life..." (Sheyko, Bohutskyi \& Germanova de Diaz, 2012,31). Culture, in turn, is seen as a subsystem of a coherent socio-cultural structure (Sheyko and Bohutskyi, 2005, p. 337). Representatives of this school focus mainly on the study of historical and theoretical aspects of culture. The applied part of culturology is known in the West as cultural anthropology. Being concerned with the cultural characteristics of man (mentality, use of language, signs, symbols, etc.), cultural anthropology intersects with ethnography (Sheyko, Bohutskyi \& and Germanova de Diaz, 2012, p. 33). Thus, the subject of culturology is culture proper, i.e. culture as a self-sufficient institution.

Justifying the use of the term 'cultural studies' outside the Englishspeaking world, researchers rightly refer to the absence of an appropriate term in post-Soviet educational practice. In their opinion, there are significant differences between culturology and cultural studies in content, conceptual apparatus, theoretical approaches and methodology (Nurzhanov \& Yerzhanova, 2010). The term 'cultural studies' is rather vague; the grammatical form of the plural implies both methodological pluralism and the plurality of the objects being studied (Usmanova, 2001, p. 5). Another feature of cultural studies is its applied orientation. There are even voices that accuse culturologists of inability to "... work with specific cultural forms and processes, various types of texts, various cultural objects." (Zvereva, 2008). However, such criticism seems groundless because the theoretical findings of cultural anthropology (and this is a branch of culturology!) are, to a large extent, based on field studies of specific cultures.

Priority areas of cultural studies are synchronous studies of the culture of post-industrial society using the methods of semiotics, discursive analysis, 
content analysis, etc. The opponents of the cultural approach consider the focus on the phenomena of contemporary culture more relevant than the obsolete, in their view, historical principles of cultural studies (Zvereva, 2008). Another benefit of cultural studies is their distinctive interdisciplinary character. Researchers in this field use the ideas and methods of history, philosophy, sociology, literary criticism, ethnography, religious studies, art criticism, political science, aesthetics and other fields of knowledge. However, such a diversity of scientific interests cannot be regarded as an exclusive merit of cultural studies. The importance of a multidisciplinary approach to the study of culture is also emphasized today by a number of prominent culturologists (Sheyko, Kanistratenko and Kushnarenko, 2018, p. 64).

In the British model of higher education, which also includes the universities of Ireland, teaching "cultural studies" is given a proper place. The content, forms and objectives of the Irish curricula in cultural studies are drawn in this article on the material of the following portals: www. courses.ie/course-category/cultural-studies/; www.masterstudies.com/ MA/Cultural-Studies/; www.mastersportal.com/.../area-cultural-studies. html. A general description of the higher education system in Ireland can be found at https://staracademy.ua/high-education/universitety-irlandii. Irish universities, colleges, and institutes of technology offer applicants for cultural studies progrannes at the bachelor's, master's, and PhD levels. The most prestigious universities in Ireland are Trinity College Dublin, University College Dublin and University of Limerick. The international rating of these institutions is quite high: Trinity College Dublin is one of the top 100 universities in the world; University College Dublin ranks 29th among European universities.

At Trinity College Dublin you can earn a Master of Arts (MA), Master of Philology (M.Phil.) or Master of Literature (M.Litt.). The title of the degree depends on the main focus of the programme, although university prospectuses traditionally list all educational programmes in the field of culture under the common title of Master of Cultural studies.

Irish cultural specificity is represented at Trinity College Dublin by the Master's programme in Early Irish. Graduates of this course obrain the M.Phil degree. Students explore different stages of Irish language development, study the history of Irish law and literature. Course duration is 2 years. The course is completed with writing and defending a thesis 20,000 words in length.

Characteristic of the Chinese Studies programme is a combination of interdisciplinary and mixed historical and synchronic approaches to the study of culture. Students take the Chinese language and translation (theoretical and practical aspects), history, culture, social policy of China. Having successfully completed the course, students earn an M.Phil degree. 
One should also mention the M.Phil Master's Degree programme in Digital Humanities \& Culture. It is a field of knowledge and a field of research at the intersection of the humanities, computer sciences and information management. The study involves analysis, synthesis and presentation of information in electronic format, the use of digital technologies in cultural heritage preservation. Related departments offer students electives in languages, music, media, history, Celtic studies. Masters programmes in Digital Humanities \& Culture are designed for students holding a bachelor's degree in social sciences and computer science. A similar programme (PhD) is offered at Maynooth University.

University College Dublin (UCD) offers a wide range of programmes in the humanities: history, linguistics, literature, cultural studies, folklore, Irish, art history, art management, cultural policy, cinema, music, theatre, etc. UCD's College of Arts and Humanitiesists is composed of seven academic schools and a research center. Upon completion of the bachelor's course, students earn a BA Arts or BA Humanities). The Pre-University Arts, Culture and History prepares applicants for undergraduate studies in the arts, culture and history. Students gain knowledge of archeology, local lore, folklore and ethnology, contemporary European culture, and get acquainted with the basics of research, journalism, political science, organizational activities and communication. Similar courses are available at Laoghaire Further Education Institute, National University of Ireland Maynooth, Dunboyne College of Further Education and other institutions.

Maynooth University is the youngest university in Ireland. Within the framework of the international SOCRATES programme, this institution offers a unique Master's course (MA) under the title Cultural Differences \& Transitional Processes. Other participants of the project are the universities of Vienna, Barcelona, Lyon, Ljubljana and Stockholm. The programme requires that each student is to attend classes at one of the partner universities for 2 semesters. This format makes it possible to study other societies, cultural differences and transnational problems "in their home countries".

Equally interesting is the practice of educating $\mathrm{PhDs}$ in inter-university cooperation programmes within Ireland proper. For example, the Philosophy of Art \& Culture programme was jointly developed by the Departments of Philosophy of NUI Galway, Mary Immaculate College, and the History Department of Limerick University. Students of this course can make use of the experience and intellectual resources of the three educational institutions. PhD graduates receive their degrees at the University of Limerick.

At Master's level (MA), the University of Limerick offers the Comparative Literature and Cultural studies programme. This unique programme 
provides a comparative analysis of the functioning of literature, culture and the arts in the different societies, and their impact on the formation of collective identity. Core disciplines also include theory of literature and culture; comparative studies of world literature and culture; language and culture, and cultural identity as text. Elective courses: gender, culture and society; culture in a market economy; theory of feminist literature; Irish in American literature and culture; Irish-German cultural relations; German literature and culture in the European context; transitional processes in culture based on literature and film in Spain in the 1970s - 1990s; issues of the universal in contemporary French literature. Enrollment in one of the latter four courses requires knowledge of German, Spanish or French, respectively. Some of the courses were developed as part of a collaboration agreement between the University of Limerick and NUI Galway.

Mary Immaculate College, although not one of the largest HEAs, has a respectable scientific and pedagogical base. The European Thought \& Culture Master's course is closely related to Ukrainian cultural disciplines. In diachrony, the programme explores the origins, characteristics and evolution of Europe's intellectual movements, and in synchrony, it deals with their impact on the current state and problems of European civilization.

The list of master's programmes presented in the Courses.ie portal under the titles Cultural studies also includes the MA course "Design History \& Material Culture" at the National College of Art \& Design, Dublin. Dún Laoghaire Institute of Art Design and Technology offers the MA programme in Public Culture Studies. The programme is based on a multidisciplinary approach to the study of culture. Culture is studied in connection with the life of society, i.e. with politics, ideology, social communications. Theoretical principles, conceptual apparatus and methods of research in art, political science, media studies are all used in this programme. Students explore human behavior in society, social movements, mechanisms of government, issues of cultural policy, the functioning of the arts and the media in society. The programme consists of the following modules: Theory of Culture and Society; Research Methodology; Academic Writing; Culture as Text: a Critical Approach; Relationship between Culture and Society; Cultural Policy and Practice. Upon completion of the course, graduates are expected to be able to analyse and critically evaluate public policy in the field of culture, interpret public documents, solve complex and unexpected problems of the relationship between culture and society.

The rich cultural heritage of the Irish people is a matter of national pride and national concern in Ireland. Irish language and culture are taught not only at the largest universities in the country. Programmes in Early Irish Studies, M.Litt. are offered, in particular, at Maynooth University. Irish 
folklore is studied as a major at Crumlin College of Further Education. Students get acquainted with various aspects of folk art such as traditional music, architecture, rituals, beliefs, legends, folk medicine, fairy tales and so on. The NUI Galway Center for Adult Learning \& Professional Development offers a degree in Irish Studies Online. This online course in Irish culture combines elements of folklore, ethnographic studies and literature with a multidisciplinary approach characteristic of cultural studies. Ireland's traditional culture (music, dance, archeology), history and literature are studied together with political science and history courses.

The Courses.ie portal also includes the Cultural Event Management course designed for students holding bachelor's degree. A similar programme is offered, for example, by Dún Laoghaire Institute of Art Design and Technology. The course provides students with knowledge and skills at the intersection of culture, art and business. Upon completion of the course they obtain a master's degree in cultural events management.

Conclusion. In Ireland, university degree programmes, known under the common title of "Cultural studies", differ in content and methodological approaches. Of the 16 programmes analyzed, only 4 meet the criteria of the British school of Cultural studies (multidisciplinary approach, application of different methodological approaches, analysis of cultural forms as texts, emphasis on the study of cultural institutions of modern society). Theoretical issues of culture are explored at classical universities, whereas the programmes of smaller education institutions are of more practical character. The content and research methodology of most analysed programmes are more similar to Ukrainian courses in ethnography, folklore, literary, and the arts. Worth studying is the experience of international and inter-university cooperation projects with comparative analysis of different cultures. In this context, the arguments in favor of replacing cultural studies with "more advanced" cultural studies seem far-fetched and unfounded. One cannot but agree with the statement by Ukrainian researcher O. V. Kravchenko that cultural studies, which reflect the specifics of the "post-Soviet intellectual situation", go beyond the "stagnant Soviet ideological paradigms" (Kravchenko, 2013). A specific feature and indisputable advantage of Ukrainian school of culturology is a combination of historical, theoretical and applied components. For instance, the educational programmes for future culturologists at Kharkiv State Academy of Culture feature the following topics: Semiotics and Hermeneutics; Postmodern Culture; Text Analysis, etc.). Archeological, ethnological field work and museum practice are part of educational process. However, in our opinion, it would be advisable to supplement the curriculum with a special course analyzing the experience of teaching cultural studies at Western universities. 


\section{References}

Zvereva, G. (2008). Culturology or cultural studies? Retrieved from https://www.hse. ru. [in Russian].

Kravchenko, O. (2013). Culturology in the context of academic cultural traditions. Kultura Ukrainy, (42), 59-70. [in Ukrainain].

Nurzhanov, B. G. \& Yerzhanova, A. M. (2010). What is cultural studies? A field of research in culturology. Retrieved from https://articlekz.com. [in Russian].

Usmanova, A. (2001). Gender and culture in the paradigm of cultural studies. St. Petersburg: Apeteia. [in Russian].

Sheyko, V. M., Kanistratenko \& M. M., Kushnarenko, N. M. (2018). Principles and priorities of research at higher education institutions in the field of culturology and art. Visnyk Kharkivskoii derzhavnoii akademii kultury, (52), 61-70. [in Ukrainain].

Sheyko, V. M., Bohutskyi, Yu. P. \& Germanova de Diaz, Ye. V. (2012). Culturology: A textbook. Kyiv: Znannia. [in Ukrainain].

Sheyko, V. M. \& Bohutskyi, Yu. P. (2005). Formation of basics of culturology in the era of civilizational globalization. Kyiv: Geneza. [in Ukrainain].

Durham, M.G. \& Kellner D.M. (Eds.) (2012). Media and Cultural studies: Keyworks. Oxford: Wiley-Blackwell. [in English].

During, S. (Ed.) (1999). The cultural studies reader. London: Routledge. [in English]. Grossberg, L., Radway, J. (Eds.) (1994). Cultural studies. London: Routledge. [in English].

Trend, D. (Ed.). (2001). Reading Digital Culture. Oxford: Wiley-Blackwell. [in English].

Надійшла до редколегії 16.10.2019 р. 